
(анализ отечественного и зарубежного опыта)

Статья посвящена анализу отечественного и зарубежного опыта преподавания иностранных языков. Авторы рассматривают терминологический аппарат, приводя трактовки понятий «метод», «прием», «технология». В диахроническом аспекте представлены цели обучения ИЯ в разные периоды и их эволюция; а также описаны методы, применяемые в процессе обучения ИЯ. Появление новых методов связано с изменяющимися условиями существования общества, развитием научно-технического прогресса, характером межличностных отношений. Новые образовательные программы призваны обеспечить подготовку специалиста к обучению через всю жизнь. Сам процесс обучения должен максимально раскрыть все возможности индивида и облегчить ему усвоение профессиональных компетенций. Добиться этой цели возможно, сочетая технологию развивающего обучения, групповой и коллективной деятельности, проектную технологию и технологию обучения в сотрудничестве / Kooperatives Lernen». Применение представленных в статье технологий обеспечивает искомый результат, что доказывают данные проведенного опытного исследования. Авторы приходят к выводу, что универсального метода обучения ИЯ не существует. Но, как показывает опыт, комбинирование различных методов гарантирует развитие и совершенствование профессиональных компетенций.

Ключевые слова: метод, технология, иностранный язык, обучение, компетенция, деятельность, сотрудничество

\title{
On the Way of the Search of New Methods in Teaching Foreign Languages (Analysis of Domestic and Foreign Experience)
}

The article is concerned with analysis of domestic and foreign experience in teaching foreign languages. The authors investigate terminological apparatus, providing explanations of notions "method", "technique", "technology". The objectives of teaching foreign languages in various periods and their evolution are presented in diachronic aspect; and the methods applied in teaching foreign languages process are have been described. New methods emergence is connected with varying conditions of existing society, scientific and technical progress, kinds of interpersonal relationships. New educational programs are aimed to enable the specialist to be educated throughout his whole life. The teaching process itself should disclose to the fullest degree all possibilities of individual and simplify him mastering the professional competence. This goal achievement is possible by combining developmental teaching process, collective and team activities, design technology and training technique in cooperation / "Kooperatives Lernen». The use of the presented in this article techniques stipulate the result sought for, which is proven by conducted experimental study results. The authors come to the conclusion that no best possible foreign languages teaching method exist. Nevertheless, as shown by experience, the combination of various methods guarantees the professional competence development and improvement.

Key words: method, technology, foreign language, training, competence, activities, cooperation 


\section{Преподаванию чрезвычайно вредит тенденция замыкаться в рамках какого-либо одного «милого сердиу» метода} И.Л. Бим

\section{Введение}

M ема выбора методов в обучении иностранным языкам не нова и никогда не устареет. Об этом говорит история развития вопроса и современность. Именно в XX веке возникло бесчисленное множество новых методов, претендовавших и претендующих на лучшие результаты обучения иностранному языку (далее ИЯ) в школе и вузе. Сегодня предпринимаются попытки подвести определённые итоги жарких споров о рациональном методе обучения иностранным языкам, установить причины эволюции или инволюции, выявить тенденции изменения методов в обозримом будущем [2, 3, 5, 19 и др.].

Вместе с изменением методов интенсивно развивалось само понятие метод обучения, как в отечественных, так и зарубежных теориях преподавания и изучения языков. В настоящее время оно не имеет строго однозначного терминологического обозначения в разных странах мира, в том числе и в России.

Так, русскому термину метод в современной зарубежной литературе могут соответство- вать не только термины method (англ.), Methode (нем.), méthod (фр.), но и approach (англ.), Ansatz, Strategie, Verfahren (нем.), approche (фр.), то есть термины, обозначающие в российской терминологии подход.

Memod (греч. Methodos - путь, способ) используется в отечественной методике ИЯ в двух значениях. В широком смысле слова метод - это принципиальное направление обучения, методическая система, характеризующаяся своими целями, содержанием, принципами и приёмами обучения. Метод в широком смысле слова понимается как общее генеральное направление, как целостная стратегия обучения ИЯ в тот или иной, конкретный исторический период. В связи с этой трактовкой в истории методики принято рассматривать переводные, прямые, смешанные методы, аудиолингвальный, аудиовизуальный, натуральный, коммуникативный и др. методы [1].

Материалы и методы

Основываясь на анализе развития методов обучения ИЯ в XX веке В.Л. Витлина [4, с. 27-28], представим его выводы в виде таблицы (см. табл.1).

Таблица 1

Эволюция методов обучения ИЯ в России в XX веке

\begin{tabular}{|c|c|c|c|c|}
\hline $\begin{array}{l}\text { Примерная } \\
\text { периодиза- } \\
\text { ция }\end{array}$ & $\begin{array}{l}\text { Основные ме- } \\
\text { тоды в средних } \\
\text { учебных заве- } \\
\text { дениях }\end{array}$ & $\begin{array}{c}\text { Основные цели } \\
\text { обучения Ия }\end{array}$ & $\begin{array}{c}\text { Главные теоретические } \\
\text { основы обучения ИЯ }\end{array}$ & $\begin{array}{c}\text { Основные принципы и сред- } \\
\text { ства обучения ИЯ }\end{array}$ \\
\hline \multirow[t]{2}{*}{$\begin{array}{l}\text { Конец XIX в. } \\
\text { - начало XX } \\
\text { в. (до } 1917 \\
\text { года) }\end{array}$} & $\begin{array}{l}\text { Переводные: в } \\
\text { классической и } \\
\text { женской гимна- } \\
\text { зиях (элементы } \\
\text { прямого мето- } \\
\text { да с } 1901 \text { г.) }\end{array}$ & $\begin{array}{l}\text { 1.Чтение. } \\
\text { 2.Развитие } \\
\text { мышления } \\
\text { 3.Знание ино- } \\
\text { странной лите- } \\
\text { ратуры }\end{array}$ & $\begin{array}{l}\text { Теория классического об- } \\
\text { разования в педагогике; } \\
\text { классическая филология }\end{array}$ & $\begin{array}{l}\text { Интенсивное чтение и пере- } \\
\text { воды; заучивание наизусть; } \\
\text { сравнение языков; изучение } \\
\text { грамматики на родном языке }\end{array}$ \\
\hline & $\begin{array}{l}\text { Прямые и } \\
\text { смешанные: в } \\
\text { коммерческих } \\
\text { училищах }\end{array}$ & $\begin{array}{l}\text { 1.Устная речь. } \\
\text { 2. Коммерче- } \\
\text { ская переписка }\end{array}$ & $\begin{array}{l}\text { Теория реального об- } \\
\text { разования в педагогике. } \\
\text { Младограмматизм в язы- } \\
\text { кознании }\end{array}$ & $\begin{array}{l}\text { Одноязычное обучение. } \\
\text { Диалоги, пересказы. Опора } \\
\text { на наглядность, интуицию. } \\
\text { Составление писем. Краткие } \\
\text { грамматические правила. }\end{array}$ \\
\hline $\begin{array}{l}\text { Начало 20-x } \\
\text { годов }\end{array}$ & $\begin{array}{l}\text { В основном } \\
\text { прямые }\end{array}$ & $\begin{array}{l}\text { Практическое } \\
\text { владение ИЯ } \\
\text { (устная речь, } \\
\text { чтение) }\end{array}$ & $\begin{array}{l}\text { Теория комплексной } \\
\text { системы обучения. Мла- } \\
\text { дограмматизм в языкоз- } \\
\text { нании }\end{array}$ & $\begin{array}{l}\text { Одноязычное обучение. } \\
\text { Опора на наглядность, интуи- } \\
\text { тивное понимание; чтение и } \\
\text { пересказы; сочинения }\end{array}$ \\
\hline $\begin{array}{l}\text { Середина } \\
\text { 20-x- начало } \\
\text { 30-х годов }\end{array}$ & $\begin{array}{l}\text { «Русский» } \\
\text { прямой метод. } \\
\text { Смешанные } \\
\text { методы }\end{array}$ & $\begin{array}{l}\text { 1.Чтение книги. } \\
\text { 2.Элементы } \\
\text { устной речи }\end{array}$ & $\begin{array}{l}\text { Теория комплексной си- } \\
\text { стемы обучения; бригад- } \\
\text { но-лабораторный метод } \\
\text { в педагогике. Дидактиче- } \\
\text { ские принципы }\end{array}$ & $\begin{array}{l}\text { Органичное использование } \\
\text { русского языка. Диалоги, чте- } \\
\text { ние. Перевод как средство } \\
\text { семантизации }\end{array}$ \\
\hline 30-годы & $\begin{array}{l}\text { Смешанные } \\
\text { методы }\end{array}$ & $\begin{array}{l}\text { 1.Чтение книги. } \\
\text { 2.Элементы } \\
\text { устной речи. }\end{array}$ & $\begin{array}{l}\text { Принцип сознательности } \\
\text { и другие дидактические } \\
\text { принципы; } \\
\text { традиционная классно- } \\
\text { урочная система (с } 30-x \\
\text { годов и далее) }\end{array}$ & $\begin{array}{l}\text { Чтение - ведущий вид рече- } \\
\text { вой деятельности. } \\
\text { Учёт родного языка, сравне- } \\
\text { ние с ним. Систематическое } \\
\text { изучение грамматики }\end{array}$ \\
\hline
\end{tabular}




\begin{tabular}{|c|c|c|c|c|}
\hline 40-е годы & $\begin{array}{l}\text { Переводные } \\
\text { и смешанные } \\
\text { (сознательно- } \\
\text { сопоставитель- } \\
\text { ный подход) }\end{array}$ & $\begin{array}{l}\text { 1.Чтение и пере- } \\
\text { вод. 2.Элементы } \\
\text { устной речи. } \\
\text { 3.Общее разви- } \\
\text { тие учащихся. }\end{array}$ & $\begin{array}{l}\text { Лингвистическая концеп- } \\
\text { ция Л.В.Щербы (активная } \\
\text { и пассивная грамматика } \\
\text { и др.); } \\
\text { принцип сознательности } \\
\text { и другие дидактические } \\
\text { принципы }\end{array}$ & $\begin{array}{l}\text { Одновременное развитие } \\
\text { всех видов РД. Сравнение } \\
\text { языков. Дифференциро- } \\
\text { ванный подход к обучению } \\
\text { активному и пассивному } \\
\text { владению ИЯ (конец 40-х - } \\
\text { начало 50-х годов) }\end{array}$ \\
\hline 50-е годы & $\begin{array}{l}\text { Переводный } \\
\text { (сознательно- } \\
\text { сопоставитель- } \\
\text { ный подход) }\end{array}$ & $\begin{array}{l}\text { 1.Чтение. } \\
\text { 2. Элементы } \\
\text { устной речи. } \\
\text { 3.Общее разви- } \\
\text { тие учащихся. }\end{array}$ & $\begin{array}{l}\text { Интерпретация работ } \\
\text { И.В.Сталина по языкоз- } \\
\text { нанию. Дидактический } \\
\text { принцип сознательности. } \\
\text { Идеи коммунистического } \\
\text { воспитания (до середины } \\
\text { 80-х годов) }\end{array}$ & $\begin{array}{l}\text { Систематические теоретиче- } \\
\text { ские пояснения. Усиленная } \\
\text { роль грамматики и сопостав- } \\
\text { лений с русским языком. } \\
\text { Прямые и обратные перево- } \\
\text { ды (устные, письменные) }\end{array}$ \\
\hline 60- годы & $\begin{array}{l}\text { Умеренно-пря- } \\
\text { мые (в одних } \\
\text { школах) или } \\
\text { сознательно- } \\
\text { сопоставитель- } \\
\text { ные (в других } \\
\text { школах) }\end{array}$ & $\begin{array}{l}\text { Устная речь и } \\
\text { чтение }\end{array}$ & $\begin{array}{l}\text { Теория умений и навыков } \\
\text { в психологии. Элементы } \\
\text { кибернетики и структур- } \\
\text { ная лингвистика (до на- } \\
\text { стоящего времени) }\end{array}$ & $\begin{array}{l}\text { Обучение на устной основе. } \\
\text { Коммуникативный подход. } \\
\text { Использование речевых об- } \\
\text { разцов и ТСО (кинофильмы, } \\
\text { диафильмы, пластинки). } \\
\text { Индуктивное изучение грам- } \\
\text { матики. Элементы програм- } \\
\text { мированного обучения и } \\
\text { аудиовизуального метода }\end{array}$ \\
\hline $\begin{array}{l}70-е \text { годы и } \\
\text { начало 80-х } \\
\text { годов }\end{array}$ & $\begin{array}{l}\text { Смешанный } \\
\text { (комбиниро- } \\
\text { ванный) }\end{array}$ & $\begin{array}{l}\text { Устная речь и } \\
\text { чтение }\end{array}$ & $\begin{array}{l}\text { Деятельностный подход } \\
\text { к обучению. Формирова- } \\
\text { ние умений и навыков. } \\
\text { Элементы теории ис- } \\
\text { пользования психических } \\
\text { возможностей человека } \\
\text { (суггестопедия и др.) }\end{array}$ & $\begin{array}{l}\text { Коммуникативный под- } \\
\text { ход. Устный вводный курс и } \\
\text { устное опережение; ролевые } \\
\text { игры. Использование от- } \\
\text { ечественных УМК. Усиленная } \\
\text { роль ТСО. Индуктивное из- } \\
\text { учение грамматики. Элемен- } \\
\text { ты интенсивных методов и } \\
\text { т.п. }\end{array}$ \\
\hline $\begin{array}{l}\text { Конец 80-х } \\
\text { годов и 90-е } \\
\text { годы }\end{array}$ & $\begin{array}{l}\text { Плюрализм ме- } \\
\text { тодов в разных } \\
\text { типах средних } \\
\text { школ }\end{array}$ & $\begin{array}{l}\text { 1.Устная речь, } \\
\text { чтение, письмо. } \\
\text { 2.Комплекс- } \\
\text { ное развитие, } \\
\text { образование и } \\
\text { воспитание лич- } \\
\text { ности. }\end{array}$ & $\begin{array}{l}\text { Деятельностный подход к } \\
\text { обучению; формирование } \\
\text { умений и навыков; теория } \\
\text { гуманистического раз- } \\
\text { вития личности. Теория ис- } \\
\text { пользования психических } \\
\text { возможностей человека }\end{array}$ & $\begin{array}{l}\text { Коммуникативный подход. } \\
\text { Одновременное развитие } \\
\text { всех видов РД. Использо- } \\
\text { вание отечественных и } \\
\text { зарубежных УМК, разных } \\
\text { программ, но единых госу- } \\
\text { дарственных стандартов. } \\
\text { Усиление роли ТСО, само- } \\
\text { стоятельности учащихся, } \\
\text { элементов интенсивных и } \\
\text { т.п. методов }\end{array}$ \\
\hline
\end{tabular}

И.Л. Бим утверждает, что методика обучения как наука на протяжении своего развития отражала тот или иной метод как систему обучения в конкретных учебно-методических комплексах (УМК), которые, в свою очередь являются моделью реализации методики в конкретный исторический период [2]. Достаточно заглянуть в УМК того или иного времени, и понятным становится главенствующий метод, а также этап развития методики в период создания этого УМК.

Немецкие ученые Г. Нойнер и Х. Хунфельд подхватили эту мысль и предложили анализ методов обучения с точки зрения их представленности в структурных элементах учебника ИЯ (см. табл. 2).

Также этими учёными подробно описаны методы обучения Ия в методике, от грамматикопереводного метода до коммуникативного [20].

Помимо обозначения всей системы или всего направления обучения метод в узком смысле слова может обозначать отдельные элементы системы (метод обучения лексике, метод обучения чтению, метод тренировки грамматики и т.д.). В этом случае термин метод используется в отечественной литературе в значении приём обучения.

В этой статье нас интересует понимание метода как пути и способа достижения определённой цели в преподавании / обучении и учении. Метод как «основной структурно-функциональный компонент деятельности учителя и учащихся» $[2$, c.228]. Анализируя структуру деятельности учителя и ученика, отечественные методисты выделяют следующие методы (см.табл. 3).

Очевидно, что каждому из названных выше методов обучения ИЯ сопутствует контроль, включающий коррекцию речевых и неречевых действий учащихся и оценку их достижений. Методы учения и методы обучения прямо соотносятся друг с другом, что обеспечивает в конечном итоге взаимодействие обучающихся и учителя в учебном процессе. 
Взаимосвязь учебника и методов обучения Ия

\begin{tabular}{|c|c|}
\hline В МЕТОДАХ обучения сформулированы & В УЧЕБНИКЕ МеТОДЫ ВИДНЫ В \\
\hline $\begin{array}{l}\text { ЦЕЛИ ОБУЧЕНИЯ } \\
\text { ЧЕМУ следует обучать (учебные материалы)? } \\
\text { При этом учитываются: } \\
\text { • } \quad \text { знания из области социологии, педагогики; } \\
\text { • } \quad \text { исследования предметных наук (лингвистика, } \\
\text { страноведение, литература и науки о тексте); } \\
\text { ПРИНЦИПЫ ОБУЧЕНИЯ } \\
\text { КАК должно строится обучение? } \\
\text { Разработки делаются с учётом исследований в обла- } \\
\text { сти теории обучения в: } \\
\text { - } \quad \text { организации обучения; } \\
\text { формах обучения; } \\
\text { - } \quad \text { средств обучения; } \\
\quad \text { построении обучения }\end{array}$ & 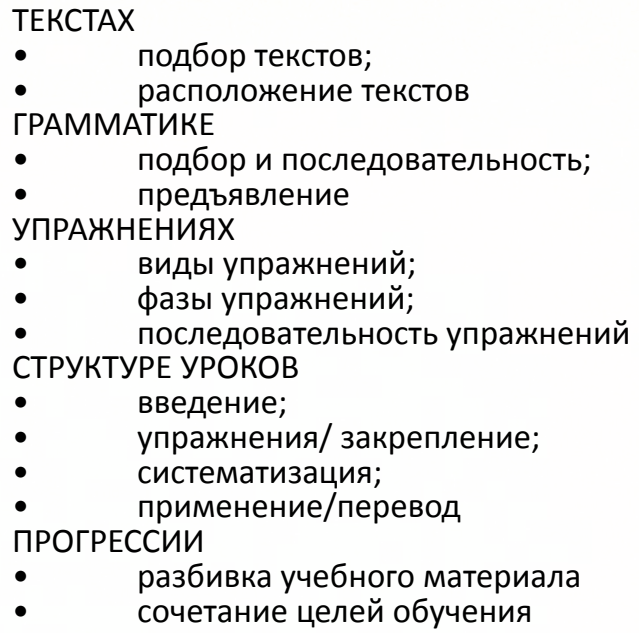 \\
\hline
\end{tabular}

Методы учения и методы обучения в методике обучения иностранным языкам

Таблица 3

\begin{tabular}{|c|c|}
\hline Методы учения в деятельности ученика & Методы обучения в деятельности учителя \\
\hline $\begin{array}{l}\text { Ознакомление (с новым словом, грамматическим } \\
\text { явлением, звуком, текстом и др.), включающее } \\
\text { чувственное восприятие, наблюдение, размышление } \\
\text { - осознание }\end{array}$ & $\begin{array}{l}\text { Организачия ознакомления, включающая показ } \\
\text { (картинки, предмета, звуковой и графической формы } \\
\text { слова, речевого образца) и объяснение (значения и } \\
\text { употребления языковых средств общения) }\end{array}$ \\
\hline $\begin{array}{l}\text { Тренировка в употреблении слов и образцов обще- } \\
\text { ния (основу тренировки составляют упражнения по } \\
\text { формированию речевых навыков и умений) }\end{array}$ & $\begin{array}{l}\text { Организация тренировки в употреблении языковых и } \\
\text { речевых средств общения }\end{array}$ \\
\hline $\begin{array}{l}\text { Применение усвоенного материала в различных ситу- } \\
\text { ациях общения в аудировании, чтении и письме (ос- } \\
\text { нову применения составляют упражнения и задания } \\
\text { по формированию речевых умений и способности к } \\
\text { межкультурному общению) }\end{array}$ & $\begin{array}{l}\text { Организация применения осваиваемого материала } \\
\text { учащимися в общении при восприятии иноязычной } \\
\text { речи на слух, чтении, говорении, письме }\end{array}$ \\
\hline
\end{tabular}

Известно, что эффективность того или иного метода зависит от составляющих его приёмов: насколько они целесообразны для конкретных условий обучения с точки зрения поставленных целей, в какой мере они ставят обучающегося перед необходимостью мыслительного усилия и эмоционального сопереживания и др.

Что же влияет на появление новых методов (а, следовательно, приёмов и их комбинаций) в обучении ИЯ? По нашему мнению, следующие факторы:

- новые знания в области лингвистики, психологии, педагогики; новое в смежных с методикой науках: в психолингвистике, межкультурной коммуникации, страноведении, культурологии, литературе, истории и т.д.;

- новый опыт в преподавании различных языков (в том числе родного языка) в различных целевых группах;

- традиции преподавания и изучения конкретного языка у себя в стране и за рубежом; представления о стране изучаемого языка;

- развитие самой методики как науки;
- условия обучения в каждом конкретном учебном заведении: количество учебных часов, наличие профессиональных кадров, наличие современных средств обучения, достаточных и доступных всем студентам в группе.

Как представляется, последний фактор играет в последнее время важную роль в системе высшего образования в нашей стране.

\section{Результаты исследования}

Система преподавания ИЯ в школе и вузе сейчас переживает этап реформирования. Это касается не только пересмотра целей и методов обучения ИЯ, но и терминологии.

Как мы знаем, в основе подготовки современного специалиста-лингвиста лежит компетентностный подход, который закреплён во ФГОС-программах по подготовке бакалавров и магистров в высшей школе [15]. Этот подход предусматривает развитие ключевых компетенций в терминах «знать», "уметь», «владеть». Применительно к языковому образованию это - 
готовность и способность студента осуществлять иноязычное общение в определённых стандартом пределах [6].

Как преподаватели-практики, мы замечаем, что новая терминология в нормативных документах не уводит нас от цели, а лишь трактует её немного иначе. Представим перечень необходимых лингвисту компетенций в ходе подготовки по дисциплине «Практический курс первого иностранного языка» в соответствии с п. 5.1 стандарта: «В результате освоения программы бакалавриата у выпускника должны быть сформированы общекультурные, общепрофессиональные и профессиональные компетенции, а именно:

- ОК-5: способен работать в команде, толерантно воспринимать социальные, культурные и личностные различия;

- ОПК-5: владеет основами профессиональной этики и речевой культуры;

- ПСК-2: владеет системой лингвистических знаний, включающей в себя знание основных фонетических, лексических, грамматических, словообразовательных явлений и закономерностей функционирования изучаемого иностранного языка, его функциональных разновидностей;

- ПСК-3: умеет свободно выражать свои мысли, адекватно используя разнообразные языковые средства с целью выделения релевантной информации [15].

Очевидно, что сами знания и компетенции, вне определённых навыков и умений их использования, не решают проблему образования человека и его подготовки к реальной деятельности вне стен учебного заведения. В документах Совета Европы по языковому образованию эта концепция получила название Long Life Learning (LLL), т.e. обучение на протяжении всей жизни [9].

Уверены, что для того, чтобы разрабатывать новые учебные программы, необходимо, с одной стороны, следовать общей логике, принятой в государственном стандарте, с другой, учитывать веяния времени, а именно ориентироваться на компетентностный подход и методы, направленные на LLL-стратегии в подготовке бакалавров со знанием ИЯ.

Проблема, рассматриваемая в рамках данной статьи, представляется нам актуальной, поскольку связана с накопленным опытом использования различных методик преподавания ИЯ в вузе. Преподаватели высшей школы используют такие методы обучения, которые способствуют не только развитию достигнутого еще в школе уровня коммуникативной компетенции, но и обеспечивают ее рост. Достичь этого позволяет опора на уже знакомые обучающимся методы, а также использование новых эффективных методов обучения ИЯ.

Сегодня в педагогической науке твёрдо закрепился термин «технология» для обозначения способа или совокупности действий учителя и ученика в образовательной деятельности. Тем самым, произошла некая замена термина «метод в узком смысле слова» на термин «технология». Так, в «Лингводидактическом энциклопедическом словаре» А.Н.Щукина мы находим такое определение: «Технология обучения - совокупность наиболее рациональных способов научной организации труда, обеспечивающих достижение поставленной цели обучения за минимальное время с наименьшей затратой сил и средств» [16, с. 345].

Представим более подробно технологии, которые на наш взгляд, максимально точно соответствуют такому подходу на современном этапе. Они современны, научны, рациональны, соответствуют целям обучения, не требуют больших затрат и сил как со стороны преподавателя, так и со стороны студента.

По мнению Полозовой Е.А., к ним можно отнести технологию развивающего обучения, групповой и коллективной деятельности, проектную технологию. Все они могут быть применены на любом учебном предмете и носят надпредметный характер [10].

В отечественной и зарубежной методике активно применяется технология обучения в сотрудничестве / «Kooperatives Lernen». Отечественные методисты видят в этой технологии совместную деятельность учителя и обучающегося, основанную на индивидуальном подходе к ребенку в результате психолого-педагогической диагностики, когда педагог опирается в преподавании не на предмет обучения, а на индивидуальные возможности ученика.

В зарубежной методике под Kooperatives Lernen понимаются механизмы обучения, которые требуют скоординированной работы в группе для совместного поиска решения проблемы или прогнозирования развития ситуации [18]. Технология направлена на активацию возможностей ученика посредством его работы в команде. Компетенции, которые ученик приобретает во время обучения, имеют значение для всей его дальнейшей жизни (life skills): как личной, так и профессиональной (interaction skills). С точки зрения ученых Н. Грин и К. Грин, «чем лучше человек научился работать в команде, совместно преодолевая трудности, тем выше его шансы стать успешным как в профессии, так и в личной жизни» [17, с. 65].

Технология Koоperatives Lernen состоит из 3 шагов:

- 1 шаг. Denken / обдумывание (индивидуальная работа);

- 2 шаг. Austauschen / обмен мнениями (групповая работа);

- 3 шаг. Vorstellen / представление, презентация.

Этапы работы представлены на рис.1. [17,с. 4].

На 1 этапе Denken обучающийся сначала перерабатывает новую информацию индивидуально и интегрирует ее в свою структуру знаний. Новое знание связывается с предыдущим. 


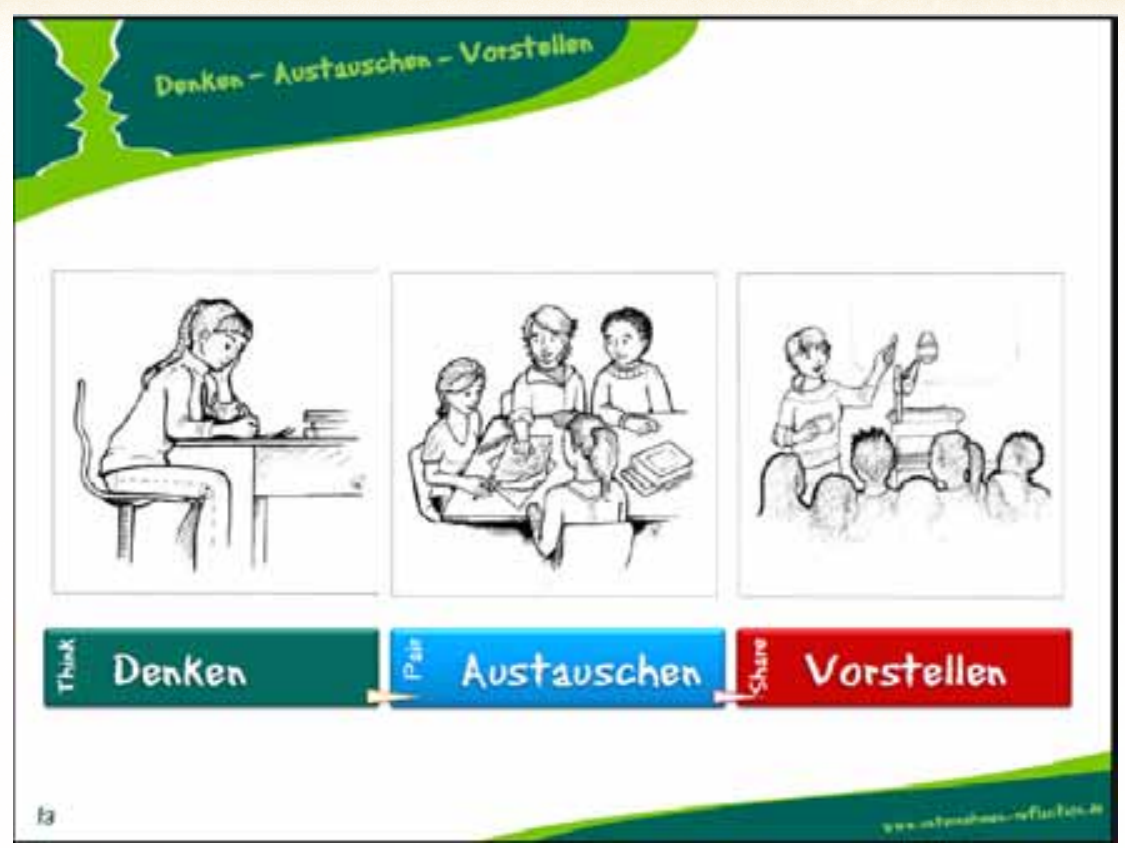

Рис. 1 Технология Kooperatives Lernen

2 этап Austauschen предполагает обмен мнениями в паре или малой группе. Этот обмен базируется на результатах индивидуальной работы: Правильно ли я понял? Что я не так понял? На этом этапе работы исправляется недопонятое, дополняется и углубляется понимание. Эта фаза обучения занимает в технологии Kooperatives Lernen центральное место, т.к. обучающийся формирует свою коммуникативную компетенцию, активирует, сравнивает и обменивается знаниями и опытом.

На этапе обсуждения может возникнуть когнитивный конфликт, который, по мнению швейцарского психолога, создателя теории когнитивного развития, Ж. Пиаже, является механизмом развития [8]. В результате происходит углублен- ное проникновение в тему, обучающиеся исправляют и расширяют собственные структуры знания. Причем, по убеждению Л. Брюнинга и Т Заума, обмен мнениями не должен приводить к повторению сказанного. Это требует от участников высокой концентрации внимания. Они учатся принимать разные точки зрения и избавляться от предрассудков. Студенты учатся не только у преподавателя, но и друг у друга. Они развивают свои структуры знания в противоречиях с чужими идеями, представлениями и результатами $[17$, c.37, 42].

Авторы приводят метод Placemat (см. рис. 2 $[17, c .25])$, который позволяет структурировать совместную рабочую деятельность и сравнивать результаты.
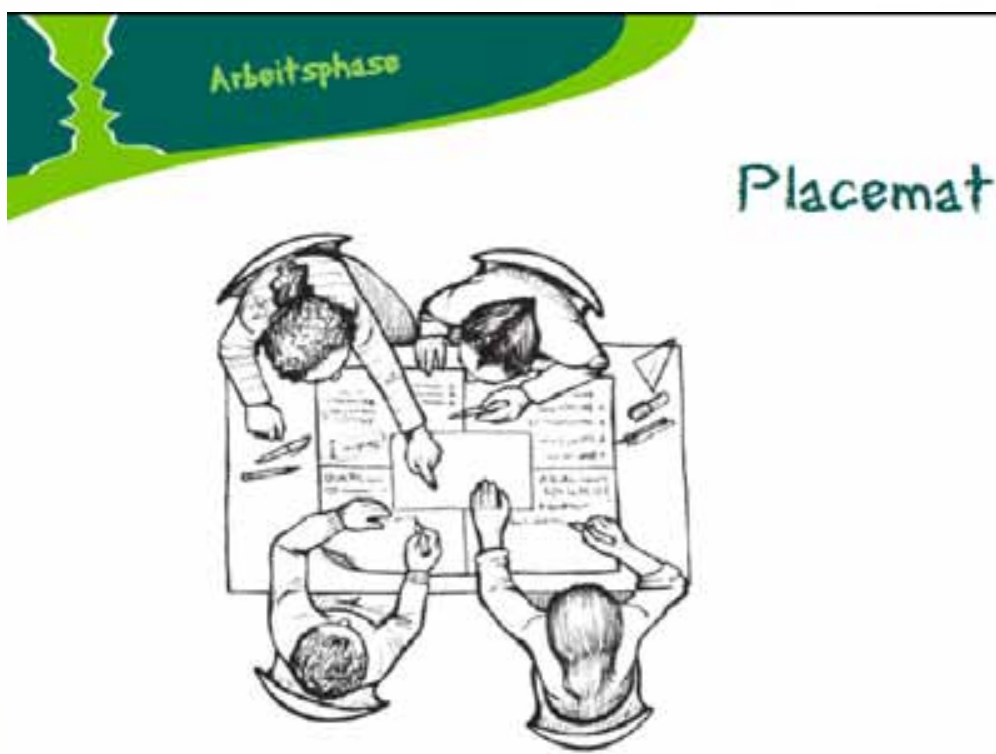

\section{Placemat}

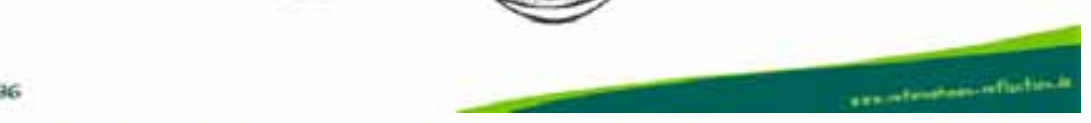

Рис. 1 Метод Placemat 
Обучающиеся сидят по периметру четырехугольника каждый со своим листком, на котором они записывают свои идеи, мысли по поводу полученного задания. В результате обмена мнениями (2 этап) они выясняют и сравнивают результаты, находят общее в суждениях, исправляют недочеты и записывают их в центральное поле. На фазе презентации именно центральный лист с общими идеями помогает представить продукт проделанной командой работы.

3 этап Vorstellen - это презентация или визуальное предъявление результатов работы, проделанной группой. Причем, авторы методики советуют выбирать презентующего случайным образом (напр., самый высокий, самый юный, первый / последний в списке по алфавиту и др.). В таком случае каждый член группы мотивирован максимально понять задание и при случае быть готовым представить продукт деятельности всей группы, в связи с этим повышается личная ответственность каждого члена команды за общий результат. Этап представления можно рассматривать и как оценку деятельности группы. На этом этапе участники находятся в «естественном и радостном состоянии эмоционального языкового контакта» [7].

Чтобы обучающийся ощущал свою принадлежность к группе и нес ответственность за нее, он должен найти сходства между членами группы, понять, чем он похож на своих партнеров. Идентичность с группой обнаруживается на основе симпатии. Психологами разработана формула: "симпатия = сходство + близость». Близость (короткая дистанция общения) изначально задается работой в малых группах, которая характерна для обучения ИЯ. Сходства в большой степени проявляются на личном уровне. Образованная случайным образом группа не может сра-

зу стать командой. Для этого нужны специальные мероприятия (Teambildende Maßnahmen) по сплочению коллектива и узнаванию личных качеств каждого участника. Идентичность с группой усиливается ситуацией успеха. Стремление создать и представить хороший продукт, мотивация работы в команде повышают ответственность каждого за конечный результат.

Обсуждение результатов

Интегративная, эффективная для формирования всех требуемых компетенций будущего лингвиста-бакалавра технология обучения в сотрудничестве активно используется авторами данной статьи в процессе преподавания, о чем мы писали в своих работах [11-14]. Так, например, наши студенты, последовательно применяя проектную технологию и технологию обучения в сотрудничестве, участвовали в разработке и презентации проектов: "Made in Germany", "Ich möchte in Deutschland studieren. Was braucht man dazu?", "Das Beste an Deutschland“, „Die Haupthelden des Buches", "Rund ums Österreich" и др.

Технология обучения в сотрудничестве была апробирована нами в ходе опытного обучения в течение 2-х лет в рамках подготовки студентов-бакалавров по направлению «Педагогическое образование (с двумя профилями) / Иностранный язык и иностранный язык (англ+нем) (нем+англ) на 3 курсе (см. табл. 4). Обучение охватило 46 студентов за два года обучения. Как показала практика, предложенное сочетание метода проектов и метода обучения в сотрудничестве является гарантом развития и совершенствования ОК, ОПК, ПСК. Более того, по этим технологиям студенты с удовольствием занимаются как в аудитории, так и самостоятельно.

Таблица 4

Результаты развития компетенций на ИЯ в ходе применения метода обучения в сотрудничестве и метода проектов в МГТУ им. Г.И. Носова

\begin{tabular}{|c|c|c|}
\hline Компетенции & $\begin{array}{c}\text { На входе, начало 3 курса (2016-17 } \\
\text { учебный год и 2017-18 учебный } \\
\text { год) }\end{array}$ & $\begin{array}{c}\text { На выходе, по завершении 3 курса } \\
\text { (2016-17 учебный год и 2017-18 } \\
\text { учебный год) }\end{array}$ \\
\hline ОК & $48 \%$ & $56 \%$ \\
\hline ОПК & $34 \%$ & $38 \%$ \\
\hline ПСК & $9 \%$ & $12 \%$ \\
\hline
\end{tabular}

Заключение

На современном этапе все усилия науки и образования направлены на формирование компетентного специалиста - личности, которая способна учиться на протяжении всей жизни, способна как к самостоятельному приобретению знаний, так и к работе в команде, основываясь на достижениях науки и техники, способна критически оценивать научные факты, делать обоснованные выводы, принимать аргументированные решения. Как этого достичь на практике?

Наблюдения показывают, что время от времени в методике ярко вспыхивает тот или иной новый метод, которому приписывается сверхъестественная эффективность и который должен помочь решить все задачи обучения Ия. То это обучение в сотрудничестве, то интернет- 
технология, то интенсивное обучение, то метод тандема, то дистанционное обучение и т.д.

Очевидно, что идеального метода пока не существует, как нет пока perpetum mobile. Наша собственная многолетняя практика позволяет говорить об эффективности рационального использования элементов различных методов для конкретных целей и условий обучения.

Требования ФГОС предполагают ориентированность программ обучения на развитие конкретных компетенций с учётом возможностей современных технологий обучения Ия.

Для достижения комплексных целей обуче- ния ИЯ в вузе необходимо сочетать обязательные занятия с дополнительными, на которых можно использовать альтернативные методы.

Новые методы и технологии обучения ИЯ должны ориентировать обучающихся на бо́льшую автономию, стремление обучаться самостоятельно, а также нацеливать на развитие потребности учиться всю жизнь.

Преподаватель обладает относительной свободой, выбирая тот или иной метод обучения на уроках ИЯ, главное в этом вопросе - максимальное соответствие метода целям обучения.

ЛИТЕРАТУРА

1. Англо-русский терминологический справочник по методике преподавания иностранных языков. СПб.: Издво «Русско-Балтийский информационный центр «БЛИЦ»», “Cambridge University Press”, 2001. C.38-55.

2. Бим И.Л. Методика обучения иностранным языкам как наука и проблемы школьного учебника. М.: Русский язык, 1977. С. 226-242.

3. Бим И.Л. Теория и практика обучения немецкому языку в средней школе: Проблемы и перспективы: учебное пособие для студентов пед. институтов. М.: Просвещение, 1988. С.16-23.

4. Витлин Ж.Л. Эволюция методов обучения иностранным языкам в XX веке // ИяШ, 2001, № 2. С.23.

5. Гальскова Н.Д. Современная методика обучения иностранным языкам: Пособие для учителя. 2-е изд., перераб. и доп. М.: Аркти, 2003. С. 115-127.

6. Зимняя И.А. Ключевые компетентности как результативно-целевая основа компетентностного подхода в образовании. Авторская версия. М.: Исследовательский центр проблем качества подготовки специалистов, 2004. С.3.

7. Никуличева Д.Б. Как найти свой путь к иностранным языкам: лингвистические и психологические стратегии полиглотов: учеб.-метод. пособие / под ред. Д.Б. Никуличева. М.: Флинта: Наука, 2009. С.4.

8. Обухова Л.Ф. Социокогнитивный подход к исследованию интеллектуального развития ребенка // Электронный журнал «Психологическая наука и образование». 2010. № 5. С. 91-105. URL: www.psyedu.ru (дата обращения: 17.09.2018).

9. Обучение на протяжении жизни в условиях новой экономики. М.: Алекс, 2006. 264 с.

10. Полозова Е.А., Спиридович Н.Е. Технология использования обучения в сотрудничестве // Педагогика online. 30.06.2014. URL: http://aneks.spb.ru/obrazovatelnye-tekhnologii/tekhnologiia-ispolzovaniia-obucheniia-vsotrudnichestve.html (дата обращения: 17.09.2018).

11. Потрикеева Е.С. Автономное обучение на языковом факультете вуза // Современные проблемы науки и образования: материалы внутривузовской научной конференции преподавателей МаГУ. Магнитогорск: МаГУ, 2012. С. 195- 196.

12. Синяева О.В. Искусство как важный компонент образовательного процесса / Искусство Германии и России: сборник материалов межвузовской научно-практ. конференции с междунар. участием под ред. М.А. Егоровой (отв. ред.), А.А.Кузиной, О.В. Синяевой, Н.Р. Уразаевой. Магнитогорск : МаГУ, 2012. С.269-271.

13. Синяева О.В. Реализация проблемного обучения с помощью метода проектов / Дни Германии в Магнитогорске: программа и доклады. Магнитогорск : МаГУ, 2011. С. 55-59.

14. Синяева О.В. Формирование готовности будущего преподавателя иностранного языка к иноязычной коммуникации в условиях поликультурной среды: дис. ... канд. пед. наук: 13.00.08. Магнитогорск, 2002. 184 с.

15. Федеральные государственные образовательные стандарты. URL: http://fgos.ru/ (дата обращения: 15.09.2018).

16. Щукин А.Н., Лингводидактический энциклопедический словарь: более 2000 единиц. М.: Астрель: АСТ: Хранитель, 2007. 746 с.

17. Brüning L., Saum T. Erfogreich unterrichten durch Kooperatives Lernen. Strategien zur Schüleraktivierung. Neue deutsche Schule Verlagsgesellschaft, mbH, Essen, 2015. $177 \mathrm{~S}$.

18. Kooperatives Lernen. Wikipedia. URL: https://de.wikipedia.org/wiki/Kooperatives_Lernen (дата обращения: 17.09.2018).

19. Neuner G. Vermittlungsmethoden: historischer Überblick // Handbuch Fremdsprachenunterricht. 4. Auflage. KarlRichard Bausch, Herbert Christ und Hans-Jürgen Krumm. A. Francke Verlag Tübingen und Basel, 2003. S.225-134.

20. Neuner G., Hunfeld H. Methoden des fremdsprachlichen Deutschunterrichts. Eine Einführung. Fernstudieneinheit 4. Langenscheidt, 1997. 184 S.

REFERENCES

1. English-Russian terminological reference book on the methodology of teaching foreign languages. Saint Petersburg, Russian-Baltic Information Center "Blitz" Publishing House, Cambridge University Press, 2001. pp.38-55. (in Russian)

2. Bim I.L. Methods of teaching foreign languages as a science and problems of a school textbook. Moscow, Russian language, 1977. S. 226-242. (in Russian) 
3. Bim I.L. Theory and practice of teaching German in secondary school: Problems and prospects: a manual for students ped. institutions. Moscow, Enlightenment Publ., 1988. pp.16-23. (in Russian)

4. Vitlin J.L. The evolution of methods of teaching foreign languages in the XX century. Foreign language at school, 2001, no. 2. p. 23.(in Russian)

5. Galskova N.D. Modern methods of teaching foreign languages: manual for teachers. 2nd ed. Moscow, Arkti Publ., 2003. pp. 115-127. (in Russian)

6. Winter I.A. Key competencies as an effective target basis of a competence-based approach in education. Author's version. Moscow, Research Center for Problems of the Quality of Training Specialists, 2004. p.3. (in Russian)

7. Nikulicheva D.B. How to find your way to foreign languages: linguistic and psychological strategies of polyglots: a textbook.-method. manual / ed. D.B. Nikulicheva. Moscow, Flinta Publ., 2009. p.4. (in Russian)

8. Obukhova L.F. Socio-cognitive approach to the study of the intellectual development of the child. Psychological Science and Education, 2010. no. 5. pp. 91-105. Available at: www.psyedu.ru (accessed 17 September 2018). (in Russian)

9. Lifelong learning in a new economy. Moscow, Alex Publ., 2006. 264 p. (in Russian)

10. Polozova E.A., Spiridovich N.E. Technology of learning in collaboration. Pedagogy online. 2014. Available at: http:// aneks.spb.ru/obrazovatelnye-tekhnologii/tekhnologiia-ispolzovaniia-obucheniia-v-sotrudnichestve.html (accessed 17 September 2018). (in Russian)

11. Potrikeeva E.S. Autonomous learning in the language department of the university // Modern problems of science and education: materials of the internal university scientific conference of teachers of the Moscow State University. Magnitogorsk, MAGU Publ., 2012. p. 195-196. (in Russian)

12. Sinyaeva O.V. Art as an important component of the educational process / Art of Germany and Russia: a collection of materials of interuniversity scientific and practical conference with int. participation under the editorship of M.A. Egorova (ed.), A.A. Kuzina, O.V. Sinyaeva, N.R. Urazayeva. Magnitogorsk, MAGU, 2012. pp. 269-271. (in Russian)

13. Sinyaeva O.V. The implementation of problem-based learning using the project method / Days of Germany in Magnitogorsk: program and reports. Magnitogorsk, MAGU Publ., 2011. pp. 55-59. (in Russian)

14. Sinyaeva O.V. Formation of the readiness of the future teacher of a foreign language for foreign language communication in a multicultural environment: Diss. PhD Ped. Sci., Magnitogorsk, 2002. 184 p.

15. Federal state educational standards. Available at: http://fgos.ru/ (accessed 15 September 2018). (in Russian)

16. Schukin A.N., Linguodidactic Encyclopedic Dictionary: more than 2000 units. Moscow, Astrel: AST: The Guardian Publ., 2007. 746 p. (in Russian)

17. Brüning L., Saum T. Erfogreich unterrichten durch Kooperatives Lernen. Strategien zur Schüleraktivierung. Neue deutsche Schule Verlagsgesellschaft, mbH, Essen, 2015. 177 S. (in German)

18. Kooperatives Lernen. Wikipedia. URL: https://de.wikipedia.org/wiki/Kooperatives_Lernen (дата обращения: 17.09.2018). (in German)

19. Neuner G. Vermittlungsmethoden: historischer Überblick // Handbuch Fremdsprachenunterricht. 4. Auflage. KarlRichard Bausch, Herbert Christ und Hans-Jürgen Krumm. A. Francke Verlag Tübingen und Basel, 2003. S.225-134. (in German)

20. Neuner G., Hunfeld H. Methoden des fremdsprachlichen Deutschunterrichts. Eine Einführung. Fernstudieneinheit 4. Langenscheidt, 1997. 184 S. (in German)

\section{Информация об авторах Михина Ольга Викторовна (Россия, г. Магнитогорск)}

Кандидат педагогических наук, доцент

Магнитогорский государственный технический университет им. Г.И.Носова

E-mail: olga-sinyaeva@yandex.ru

\section{Потрикеева Елена Сергеевна}

(Россия, г. Магнитогорск)

Кандидат педагогических наук, доцент

Магнитогорский государственный технический

университет им. Г.И.Носова

E-mail: potrikeeva@yandex.ru

\section{Information about the authors} Olga V. Mikhina

(Russia, Magnitogorsk)

PhD in Pedagogical Sciences, Associate Professor

Nosov Magnitogorsk State Technical University

E-mail: olga-sinyaeva@yandex.ru

\section{Elena S. Potrikeeva}

(Russia, Magnitogorsk)

PhD in Pedagogical Sciences,

Associate Professor

Nosov Magnitogorsk State Technical University

E-mail: potrikeeva@yandex.ru

\section{Ссылка для цитированиягост}

Михина О. В., Потрикеева Е. С. На пути поиска новых методов обучения иностранным языкам (анализ отечественного и зарубежного опыта) // Перспективы науки и образования. 2018. № 6 (36). С. 155-163. doi: 10.32744/pse.2018.6.17

\section{For Reference ${ }^{\mathrm{APA}}$}

Mikhina, O. V., \& Potrikeyeva, E. S. (2018). On the way of the search of new methods in teaching foreign languages (analysis of domestic and foreign experience). Perspektivy nauki i obrazovania Perspectives of Science and Education, 36 (6), 155-163. doi: 10.32744/pse.2018.6.17. (In Russ., abstr. in Engl.) 